\title{
Diversity and Genetic Structuration of Populations of Plutella xylostella (Lepidoptera, Plutellidae), Cabbage Farming Destroyer in Senegal
}

\author{
Toffène Diome ${ }^{1}$, Mamecor Faye ${ }^{2}$, Marième Seck ${ }^{1}$, Cheikh Tidiane Niass ${ }^{1}$, Mbacké Sembène ${ }^{1}$ \\ ${ }^{1}$ Genetic Team and Population Management, Department of Animal Biology, Faculty of Sciences and Technology, Cheikh Anta \\ Diop University, Dakar, Senegal \\ ${ }^{2}$ Laboratory of Parasitology, Department of Animal Biology, Faculty of Sciences and Technology, Cheikh Anta Diop University, \\ Dakar, Senegal \\ Email: toffene.diome@ucad.edu.sn,eltof@yahoo.fr
}

How to cite this paper: Diome, T., Faye, M., Seck, M., Niass, C.T. and Sembène, M. (2022) Diversity and Genetic Structuration of Populations of Plutella xylostella (Lepidoptera, Plutellidae), Cabbage Farming Destroyer in Senegal. Advances in Entomology, $10,1-13$.

https://doi.org/10.4236/ae.2022.101001

Received: May 13, 2021

Accepted: November 8, 2021

Published: November 11, 2021

Copyright $\odot 2022$ by author(s) and Scientific Research Publishing Inc. This work is licensed under the Creative Commons Attribution International License (CC BY 4.0).

http://creativecommons.org/licenses/by/4.0/

(c) (i) Open Access

\begin{abstract}
Plutella xylostella, pointed out as the most dangerous destroyer of cabbage (Brassica olerarea), is a cosmopolitan species. In fact, owing to its large capacity of adaptation, $P$. xylestella colonizes any kind of area. This insect can bring about up to $90 \%$ of losses on cabbage farming. To control the insect, Senegalese farmers, very often, resort to high dose of chemical pesticides which are repetitively sprayed. The use of these chemical products gives rise to different varieties of resistant insects, which results in the emergence of different haplotypes between populations. It is in such a context that this study has been undertaken. Our objective is then to contribute to the knowledge of the genetic diversity of $P$. xylostella populations in Senegal. To hit the target, PCRSequencing method has been applied on samples from the five following localities: Diofior, Malika, Mboro, Santh Ndong, and Sebikotane. P. xylostella from Mboro is genetically different from the other populations. This fact could be due to a different way of using pesticides in this area vis-à-vis of the other localities. On the other hand, between populations of P. xylostella from Diofior, Malika, Santh Ndong, and Sebikotane, there is no significant genetic difference. In other respects, phylogenetic trees reveal the existence of two clades: one with individuals from Mboro and the other one with individuals from the other four localities. $P$. xylostella from Mboro distinguishes itself from other populations and then, can be regarded as a sub-population. Thus, the phylogenetic trees reveal the existence of two groups of $P$. xylostella in Senegal.
\end{abstract}




\section{Keywords}

Brassica oleracea, Genetic Diversity, Genetic Structure

\section{Introduction}

Market gardening has become an economic activity efficiently responding to city dwellers nutrition demand. Among market garden produce, cultivation of Brassicaceae is considered, by FAO [1], as yielding the utmost important production in the world. Besides, in agro ecosystems, growing one variety of plant on a vast expanse goes naturally with a great increase of plants bio-aggressors, in particular, making crops not marketable. Thus, Brassicaceae cropped in Senegal, notably in the Niayes area, the Senegal River valley, and the "Bassin arachidier", are imperiled by manifold natural enemies. Among them, Plutella xylostella is regarded as the most dangerous for Brassicaceae cultivated in the world, especially in the subtropical area [2] [3]. It is an insect species confined to this plant family. According to Talekar and Shelton [2], verkerk and wright [4], it can breed losses assessed up to $90 \%$. In order to control the insect, Senegalese farmers, very often, resort to high dose of chemical pesticides which are repetitively sprayed. This way of fighting against this pest affects human being health and brings the insect to develop resistance. According to Gnago et al. [5], caterpillars of the P. xylostella, seem to have developed a certain resistance against the insecticide Kart 500 SP. Odhiambo et al. [6] noticed these forms of resistance to insecticides of pyrethrinoïd type and DDT (Dichloro-Diphenyl-Trichloro-ethane) too; these are abusively used at high dose by farmers [2]. The use of these chemical products gives rise to different varieties of resistant insects, which results in the emergence of different haplotypes between populations [7]. All the pollutants and insecticides are known for their high capacity of generating mutations; this increases the number of mutations in resistant individuals too. According to Pichon et al. [8], P. xylostella can be regarded as a species highly polymorphic. This has been confirmed by Marthur et al. [9] who indicated a strong genetic diversity in populations of box tree moths from different regions of southern and northern India. Differences in the degree of resistance to insecticides between populations can result from selection of different pressures attributable to the local variation in the way of using insecticides. It is in such a context, that this study has been carried out, to determine the diversity and the genetic structuration of $P$. xylostella populations in Senegal.

\section{Materials and Methods}

\subsection{Sampling}

Sampling has been done in Senegal, precisely in five localities of two agro-ecological areas. Samples have been taken on field. It consists in collecting larva of P. xylostella living on cabbage plants; see samples on Table 1 . 
Table 1. Sampled localities and corresponding agro-ecological areas.

\begin{tabular}{ccc}
\hline Sampled localities & $\begin{array}{c}\text { Number of } \\
\text { individuals }\end{array}$ & $\begin{array}{c}\text { Agro-ecological } \\
\text { areas }\end{array}$ \\
\hline Malika & 10 & Niayes \\
Diofior & 10 & Bassin arachidier \\
Mboro & 10 & Niayes \\
Sébikotane & 10 & Niayes \\
Santh Ndong & 10 & Niayes \\
\hline
\end{tabular}

\subsection{DNA Extraction, Amplification by PCR and Sequencing}

The method was referred to kit Qiagen Dneasy Tissue. The PCR did upon fragments of mitochondrial coding gene: cytochrome $b$. This gene has been amplified with the help of the primers CB1 (5'-TAT GTA CTA CCA TGA GGA CAA ATA TC-3') and CB2 (5'-ATT ACA CCT CCT AAT TTA TTA GGA AT-3'). Amplification has been dealt with in a reactionary volume of $25 \mu$ consisting of $18.3 \mu \mathrm{l}$ of water, $2.5 \mu \mathrm{l}$ of tampon $10 \times, 1 \mu \mathrm{l}$ of additional $\mathrm{MgCl}_{2}, 0.5 \mu \mathrm{l}$ of dNTP, $0.25 \mu \mathrm{l}$ of each primer, $0.2 \mu \mathrm{l}$ of taq polymerase, and $2 \mu \mathrm{l}$ extract from DNA. It is done thanks to a cyclic repetition which ensures a multiplication by 2 of the DNA targets at every cycle. It has been carried out thanks to an equipment called thermo-cycler with the following amplification conditions: initial denaturation at $94^{\circ} \mathrm{C}$ for 3 minutes, then 35 cycles of denaturation at $94^{\circ} \mathrm{C}$ for 1 minute, followed by 1 minute of hybridation at $47^{\circ} \mathrm{C}$, and a bi $t$ of DNA elongation additional to $72^{\circ} \mathrm{C}$ for 1 minute. A final elongation at $72^{\circ} \mathrm{C}$ for 10 minutes ends the PCR. Sequencing has been carried out in South Chorea.

\subsection{Genetic Analysis}

\subsubsection{Genetic Variability of Populations}

Analysis of genetic variability parameters such as the number of polymorphic or monomorphic sites, the number of mutations, nucleotidic and haplotydic diversities have been estimated with the software Mega v.5.05 [10].

\subsubsection{Genetic Structure}

Genetic distances between $P$. xylostella populations have been calculated by of Kimura 2 parameters method [11]. They have been determined thanks to the Mega software v.5.05 [10]. $\mathrm{F}_{\mathrm{ST}}$ values, in pairs, have been used to estimate the rate of migration by generation; $\mathrm{Nm}(\mathrm{N}$, the effective size of the population multiplied by the migration rate, $\mathrm{m}$ ), based on the relationship balance $\mathrm{F}_{\mathrm{ST}}=1 /$ $(2 \mathrm{Nm}+1)$. This parameter has been determined by the Arlequin software version 3.1 [12]. Molecular variance analysis (Amova), for populations, has been done on alleles' frequencies basis, using Arlequin 3.1 [12], to prove more the genetic differentiation of the populations of $P$. xylostella in Senegal. Amova analysis has been implemented using the Arlequin software version 3.1 [12] with 1000 permutations and a significant level of 0.05 . 


\subsubsection{Demographic Evolution}

It is constituted by demo-genetic tests and a Mismatch distribution analysis. To detect expansion signs of the breakdown area of $P$. xylostella populations, as well as Tajima D and the fs of Fu tests have been carried out. Moreover, the test Fs of $\mathrm{Fu}$ is very sensitive to demographic expansion, which generally founds expression in negative values. These tests have been worked out using Arlequin v. 3.1 [12]. Mismatch distribution graphs are constructed with the help of the DnaSP v. 5.10 [13]. But the indexes that go with it, particularly SSD and Rag, have been estimated owing to Arlequin v. 3.1 [14].

\subsubsection{Phylogenetic Relationships Analysis}

For high resolution concern, erection of the phylogenetic trees has been done using two different methods: Neighbor-Joining method where calculation takes into account genetic distances by using the Kimura two parameters method, and the method of maximum probability which even shows us the history of our set of data. Research process of a phylogenetic tree, by using maximum probability, implies finding the typology and the length of the tree's branches that will give us the highest probability to observe the DNA sequences in our data. The most appropriate model to build this tree is that of GTR added to the law of Gama. These two trees have been built, using Mega software v. 5.05 [10].

\section{Results}

\subsection{Genetic Variability}

In a total of two hundred eighty-nine (289) sites, we observed ten (10) mutations, hundred (100) of variable sites which were all informative in parsimony, and two hundred seventy-nine (279) invariable sites. Five (05) haplotypes were recorded, distributed as follows: haplotype 1 gathered five (5) individuals, of which four (04) belonged to the population of P. xylostella from Diofior and one to the population from Malika; as for haplotype 2, it grouped nine (09) individuals of which, one (01) was from Diofior, six (06) from Mboro, and two (02) from Sébikotane; haplotype 3 concerned the individual M17 which was from Malika; remaining individuals were shared between haplotypes 4 and 5. A strong haplotype diversity $(0.761 \pm 0.040)$ and a weak nucleotide diversity $(0.01687 \pm$ $0.00134)$ were noticed in the global sample. Moreover, when we considered separately population from each locality instead of the global one, we remarked that the number of sites of difference varied for each sample, except for the population from Santh Ndong. Value of haplotype and nucleotide diversities was the same with respect to populations considered separately (Table 2).

Estimated under the pattern of Tamura-Nei [15], substitutions of the transition type (41.84) were lower than substitutions of trans-version one (58.16\%) (Table 3).

The type of substitution was the same, either it was synonymous or not; consequently, the ratio kns $(0.0206) / \mathrm{ks}(0.0206)=1$. Among the five haplotypes, one (h2) was shared between three populations: Mboro, Sebikotane, and Diofior; two 
(02) were shared between two populations: h5 between Santh Ndong and Sébikotane, and h1 between Malika and Diofior; haplotypes $\mathrm{h} 3$ and $\mathrm{h} 4$ were private: $\mathrm{H} 3$ was only found in Mboro and h4 in Malika, suggesting a certain degree of isolation between these two populations. Haplotypes h2 and h5 were majority and more abundant in Mboro and Sebikotane. Among the five haplotypes, only one was individual and private; that was haplotype h3, only met in Mboro (Figure 1).

Table 2. Genetic variability of $P$. xylostella.

\begin{tabular}{|c|c|c|c|c|c|}
\hline Parameters & Diofior & Mboro & Malika & Sébikotane & Santh Ndong \\
\hline Number sites of difference & 08 & 01 & 04 & 10 & 00 \\
\hline Number of haplotypes & 02 & 02 & 02 & 02 & 01 \\
\hline Haplotype diversity & $0.4 \pm 0.237$ & $0.3 \pm 0.196$ & $0.4 \pm 0.237$ & $0.4 \pm 0.169$ & 00 \\
\hline Average number of nucleotide differences & 0.011 & 0.00059 & 0.00559 & 0.01518 & 00 \\
\hline Nucleotide diversity with JC & $0.011 \pm 0.00657$ & $0.00059 \pm 0.00068$ & $0.00559 \pm 0.00328$ & $0.01518 \pm 0.00584$ & 00 \\
\hline
\end{tabular}

Table 3. Rates of different types of substitutions.

\begin{tabular}{ccccc}
\hline BASE & A & T & C & G \\
\hline A & - & 11.25 & 3.29 & 4.73 \\
$\mathrm{~T}$ & 11.25 & - & 4.73 & 3.29 \\
$\mathrm{C}$ & 11.25 & 16.19 & - & 3.29 \\
$\mathrm{G}$ & 16.19 & 11.25 & 3.29 & - \\
\hline
\end{tabular}

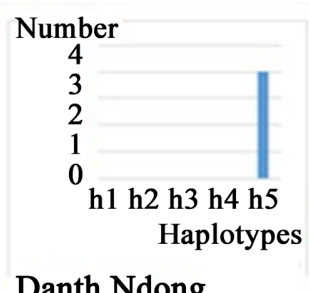

Danth Ndong

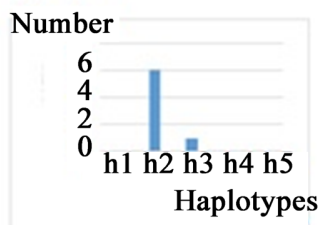

Mboro

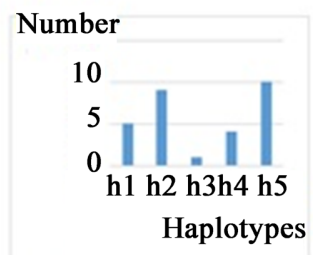

Total Population
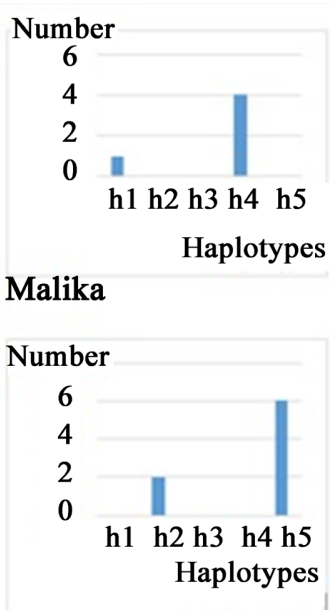

Sebikotane

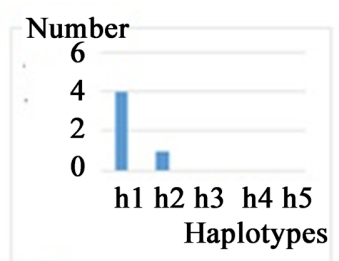

Diofior

Figure 1. Distribution of P. xylostella haplotypes (h1-5) in Senegal. 


\subsection{Genetic Structure}

\subsubsection{Genetic Distances}

In the table below, we noticed that population from Santh Ndong recorded the smallest absolute value of $d(0.000)$, followed by that from Mboro, where we had $\mathrm{d}=0.0015$, then by those from Malika and Diofior, and finally by that from Sébikotane (Table 4).

When we took into consideration the genetic distance between populations, we noticed a certain proximity between $P$. xylostella population from Diofior with those from Malika, Sébikotane, and Santh Ndong with genetic distances of 0.0166; 0.0127; and 0.0127, respectively. Genetic distances were higher between the population from Mboro and the others. Of all populations, the highest genetic distance, in absolute value, was noticed between Mboro and Santh Ndong, despite their geographic proximity, and the weakest one between Malika and Santh Ndong (Table 5).

\subsubsection{Genetic Differentiation}

It was based on various factors like the Fst mentioned above. Taking into account both the Fst and the p-value (Table 6 and Table 7), individuals of $P . x y$ lostella from Mboro were far from those of Santh Ndong, despite the geographical proximity of the two localities, and those Sébikotane and Malika as well. The genetic differentiation was significant between these different localities ( $p$-value $<0.05$ ), and confirmed the existence of distant genetic groups. On the other hand, between Sebikotane and Diofior, the p-value was non-significant ( $\mathrm{p}$-value $=0.24$ ); that showed the existence of closely related populations, with respect to genetic consideration (Table 7).

\subsubsection{Space Analysis of Molecular Variance}

The AMOVA test implemented (Table 8) allowed us to notice that variation

Table 4. Intra population genetic distances.

\begin{tabular}{ccc}
\hline Localities & Genetic distance & Standard error \\
\hline Diofior & 0.0149 & 0.0056 \\
Mboro & 0.0015 & 0.0015 \\
Malika & 0.0063 & 0.0036 \\
Sébikotane & 0.0183 & 0.0065 \\
Santh Ndong & 0.0000 & 0.0000 \\
\hline
\end{tabular}

Table 5. Genetic distances between populations.

\begin{tabular}{ccccc}
\hline Localités & Diofior & Mboro & Malika & Sébikotane \\
\hline Mboro & 0.0305 & & & \\
Malika & 0.0166 & 0.0324 & & \\
Sébikotane & 0.0170 & 0.0316 & 0.0153 & \\
Santh Ndong & 0.0127 & 0.0419 & 0.0094 & 0.0107 \\
\hline
\end{tabular}


Table 6. Comparasion of Fst, Nst, Gst and Ks between populations.

\begin{tabular}{cccccc}
\hline Population 1 & Population 2 & Ks & Fst & Nst & Gst \\
\hline Diofior & Mboro & 1.50 & 0.73 & 0.73 & 0.41 \\
Diofior & Malika & 2.40 & 0.42 & 0.42 & 0.35 \\
Diofior & Sébikotane & 3.87 & 0.13 & 0.12 & 0.38 \\
Diofior & Santh_Ndong & 1.78 & 0.55 & 0.55 & 0.64 \\
Mboro & Malika & 0.83 & 0.88 & 0.88 & 0.49 \\
Mboro & Sébikotane & 2.42 & 0.69 & 0.69 & 0.37 \\
Mboro & Santh Ndong & 0.18 & 0.98 & 0.98 & 0.69 \\
Malika & Sébikotane & 3.25 & 0.16 & 0.16 & 0.40 \\
Malika & Santh Ndong & 0.89 & 0.60 & 0.60 & 0.64 \\
Sébikotane & Santh Ndong & 2.86 & 0.14 & 0.14 & 0.06 \\
\hline
\end{tabular}

Table 7. Comparison of the p-value of Fst between populations.

\begin{tabular}{cccccc}
\hline & Diofior & Mboro & Malika & Sébikotane & Santh_Ndong \\
\hline Mboro & 0.011 & & & & \\
Malika & 0.038 & 0.003 & & & \\
Sébikotane & 0.240 & 0.002 & 0.184 & & \\
Santh Ndong & 0.010 & 0.003 & 0.003 & 0.056 & 0.547 \\
\hline
\end{tabular}

Table 8. Analysis of $P$. xylostella population structure.

\begin{tabular}{ccccc}
\hline Source of variation & d.f. & Sum of squares & Variance components & Percentage of variation \\
\hline Between populations & 4 & 42.819 & $1.68988 \mathrm{Va}$ & 61.44 \\
Within population & 24 & 25.457 & $1.06071 \mathrm{Vb}$ & 38.56 \\
Fixing Index Fst: 0.61437 & & & \\
\hline
\end{tabular}

occurred generally when populations were separately dealt with (variation between populations estimated at $61.44 \%$ ).

\subsection{Demographical Evolution}

\subsubsection{Demo-Genetic Test}

Tajima D was negative for $P$. xylostella populations from Diofior, Mboro, and Malika localities, and only significant for Diofior; on the other hand, it was positive and not significant for sébikotane. Furthermore, the test was nil for the population of $P$. xylostella from Santh Ndong. For the locality of Mboro, the Fs of Fu was not significant (Table 9).

\subsubsection{Analysis of Mismatch Distribution}

Analysis of Mismatch distribution showed a multimode curve for the global population (Figure 2).

Comparison table of the SSD or the Sum total of square deviations and the $\mathrm{Rg}$ 
Table 9. Neutrality test.

\begin{tabular}{cccccccc}
\hline & Diofior & Mboro & Malika & Sébikotane & Santh Ndong & Mean & s.d. \\
\hline D & -1.17432 & -1.00623 & -1.09380 & 0.55061 & 0.00000 & -0.54475 & 0.69388 \\
p-value & 0.04290 & 0.23720 & 0.11320 & 0.63280 & 1.00000 & 0.40522 & 0.36065 \\
Fs & 3.67939 & -0.09474 & 2.20237 & 6.05901 & 0.00000 & 2.36921 & 2.32565 \\
p-value & 0.95630 & 0.22810 & 0.83320 & 0.99640 & N.A. & N.A. & N.A. \\
\hline
\end{tabular}

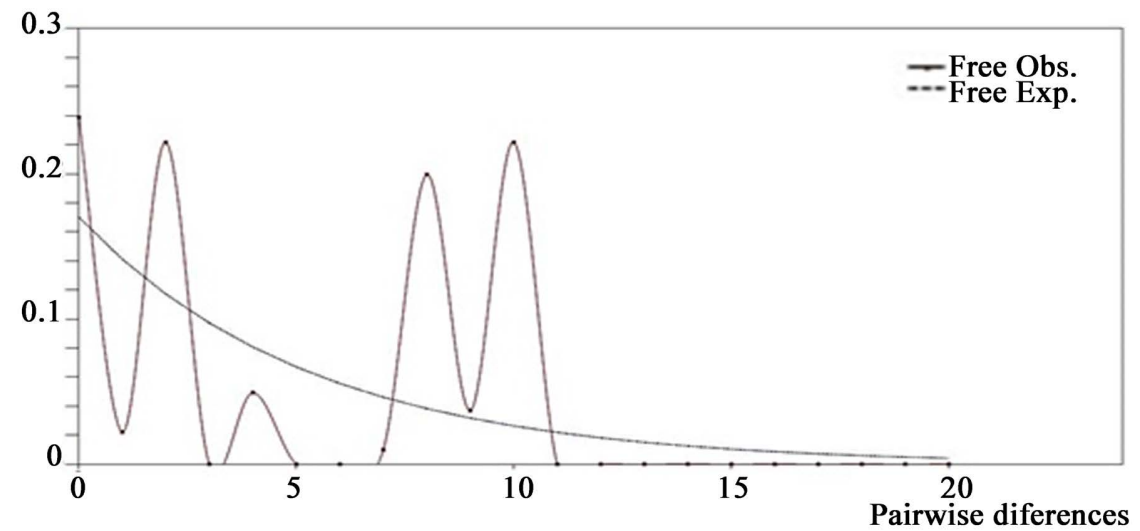

Figure 2. Distribution mismatch curve.

Table 10. Comparison of SSD and Rg by locality.

\begin{tabular}{ccccc}
\hline Locality & SSD & P-value & Rg & P-value \\
\hline Sébikotane & 0.25 & 0 & 0.68 & 0.3 \\
Santh Ndong & 0 & 0 & 0.69 & 0.5 \\
Diofior & 0.21 & 0 & 0.68 & 0.6 \\
Mboro & 0.18 & 0 & 0.26 & 0.7 \\
Malika & 0.213 & 0 & 0.28 & 0.25 \\
\hline
\end{tabular}

(Index of Irregularity) indicated that $P$. xylostella populations were composed by some well-differentiated groups. Values of SSD p-value (0.000) were significant (Table 10).

\subsection{Analysis of Phylogenetic Relationships}

The maximum probability tree showed two clades: the first one contained individuals of $P$. xylostella from four localities, namely: Santh Ndong, Sébikotane, Diofior and Malika. This clade presented a sub-clade only composed of individuals from Malika, and another one containing individuals from Diofior, Sébikotane and Santh Ndong. Individuals from Diofior distinguished themselves from others in this sub-clade. The second clade reassembled all the individuals from Mboro, two from sébikotane, and one from Diofior (Figure 3 and Figure 4).

\section{Discussion}

In spite of the weakness of our sampling, which was materialized by five populations 


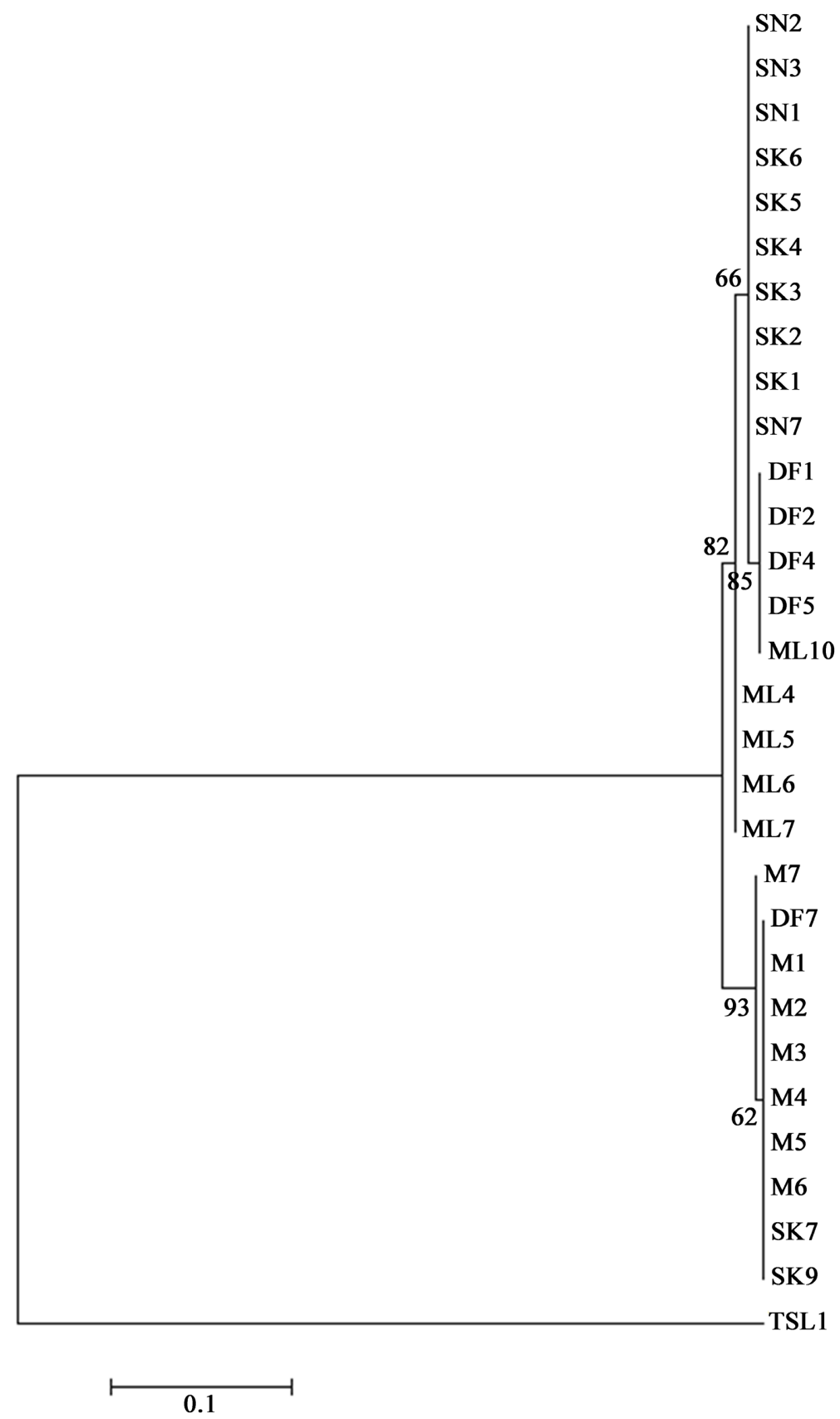

Figure 3. Neighbor-Joining (NJ) tree for P. xylostella individuals.

from five localities, with about twenty-nine sequences obtained (29), results revealed the existence of five (05) haplotypes. Our result was really important compared to that found by Saw et al. [16], who got only three (03) haplotypes out of forty-two (42) butterflies largely distributed in Australia. Sequence analysis of the mitochondrial gene COI, with $681 \mathrm{pb}$, from eighty (80) individuals gave sixteen (16) haplotypes [17]. In China, from ten (10) populations, thirty-two (32) haplotypes were detected in a sample of 149 adults [18]. In our study, most of the haplotypes were individually and essentially found in two localities; this could be an evidence of the $P$. xylostella scattering capacity. This result was akin to 


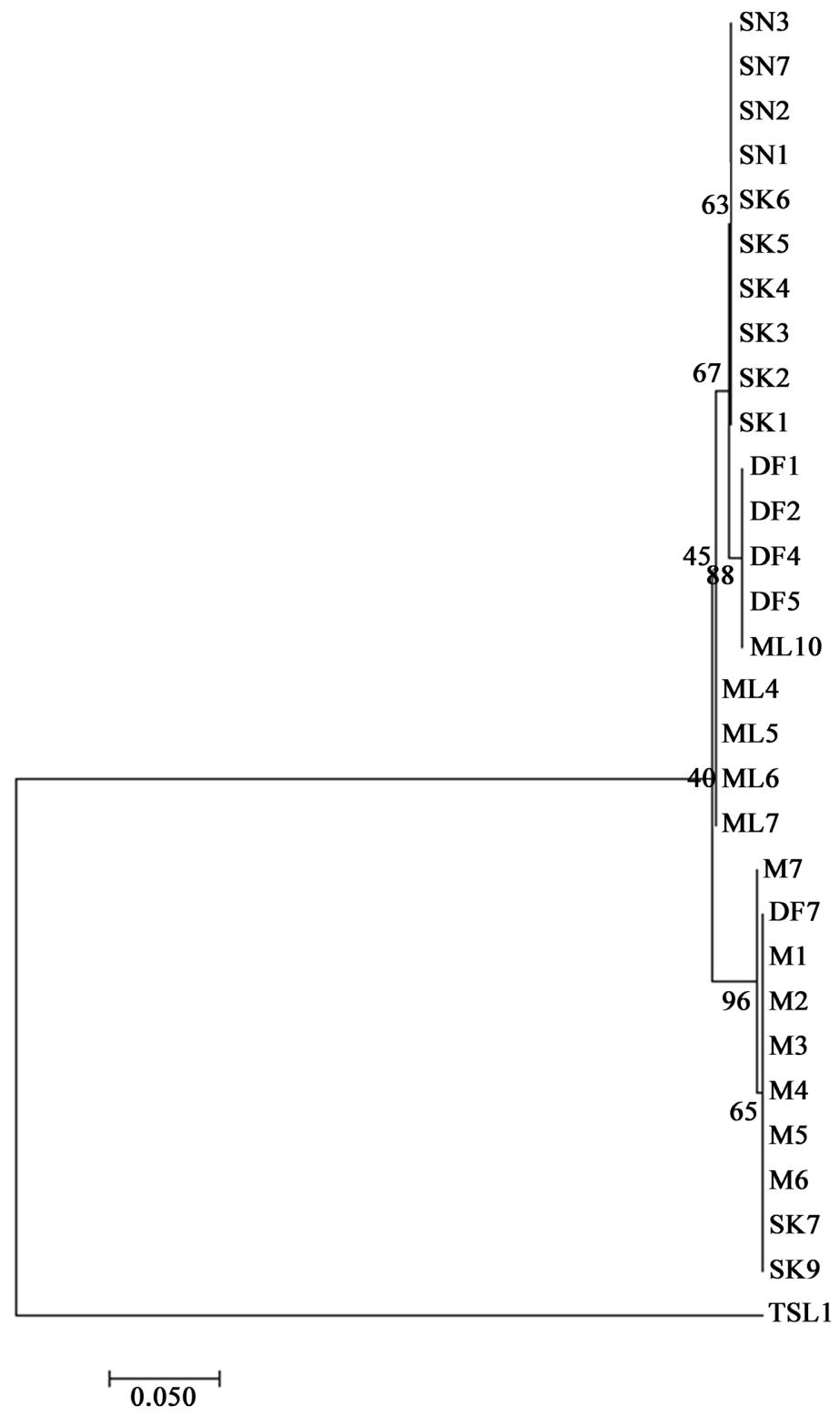

Figure 4. Maximum likelihood tree of $P$. xylostella individuals.

that of Niu et al. [18]. Analysis of the haplotype netting showed that all the two dominant haplotypes were scattered in Mboro and Sébikotane for the first one, and in Sébikotane and Santh Ndong for the other; those four localities belonged to Niayes area. We could then assume the existence of a high rate of migration between Mboro, Santh Ndong and Sébikotane localities. Radar data upheld intense migrations about P. xylostella [19], too. Moreover, studies, by Caprio and Tabashnik [20] showed that an important proportion of individuals (about 7.8\% a day) migrated; the distance could be estimated at about several thousand kilometers [21]. A strong haplotype and weak nucleotide diversities were noticed in the global sample, too. This is in accordance with Wei et al. [22] who showed a big haplotype diversity and a weak nucleotide diversity in populations of $P$. $x y$ lostella in China. In analyzing COI data, Yang et al. [23] determined that popu- 
lations of $P$. xylostella from China presented a big mitochondrial and nucleotidic haplotypes diversities. The difference observed between our study and that by Yang et al. [23] could be explained either by the weak size of our sample, or the short distances between localities in our study. The nucleotide diversity of the Australian populations of $P$. xylostella was particularly weak unlike that detected in the sample from Kenya [16]. The genetic structure showed that $P$. xylostella population from Mboro was set apart from all other populations, with significant degrees of genetic differentiation. This differentiation may be justified by a local variation of resistance against pesticides. This could be supported by Caprio and Tabashnik results [23], which indicated that the local variation about the resistance against insecticides, for the Pyrale of Diamond Hawaii population, was not an indication of a restricted genetic flow, but probably due to a local variation of selection. Other studies revealed that the largest distances between P. xylostella populations reflected probably the mass and the recurrent use of insecticides [9]. A genetic difference were noticed between strains of P. xylostella that resisted against pesticides and sensitive ones [24], but between populations at different temperatures and altitudes, too [25]. From information above mentioned, we could assume that $P$. xylostella populations would have a strong capacity of adaption and resistance against pesticides. Migratory capacities and the increasing resistance to insecticides in many populations, made the management of the species more and more hypothetical [10]. However, there was no significant genetic differentiation between $P$. xylostella populations from Diofior and Sébikotane, on one hand, and those from Sébikotane and Malika, on the other. There would have recurrent exchanges of individuals between these populations, either by migration or more likely by means of marketing. Analysis of the genetic flow of P. xylostella populations from China, by Wei et al. [21], revealed that the number of emigrants, by generation in populations from northern region, wasvery high, whereas that of the southern region was rather weak. With few genetic differentiation (Fst $=-0.038,-0.309)$ and a high rate of females, migration ( $\mathrm{Nm}=1.117$-infinite) between the Chinese populations, suggested that the scattering over long distances was a factor of demography of this species [17]. Molecular variance analysis showed that $61.44 \%$ of variation was due to a variation between populations (localities). That further consolidated the assumption that $P$. xylostella populations were structured according to pressure from pesticides. In contrast, our results were not in accordance with those of Roux et al. [9] who found that most of variability occurred within populations themselves (AMOVA: 73.71\%). Mismatch neutrality tests revealed that the population of $P$. xylostella in Senegal were stable. Phylogenetic trees showed the existence of two clades with a discrimination of individuals from Mboro in one of the clades; which one's more pointed out the peculiarity of that population. In the other clade, populations split up in two sub-clades. These two clades revealed the presence of two groups of $P$. xylostella in Senegal. Our results, were in agreement with those of Wei et al. [21] who indicated the existence of two groups of Diamond ringworm in China and worldwide. 


\section{Conflicts of Interest}

The authors declare no conflicts of interest regarding the publication of this paper.

\section{References}

[1] FAO (Food and Agriculture Organization of the United Nations) (2012) Utilisation de Bacillus thuringiensis contre Plutella xylostella en culture dechou et Phthorimaea operculella en stockage de pomme de terre. Fiche technique. Food and Agriculture Organization of the United Nations, Rome. https://www.fao.org/3/az788f/az788f.pdf

[2] Talekar, N.S. and Shelton, A.M. (1993) Biology, Ecology and Management of the Diamond Back Moth. Annual Review of Entomology, 38, 275-230. https://doi.org/10.1146/annurev.en.38.010193.001423

[3] Furlong, M.J., Wright, D.J. and Dosdall, L.M. (2013) Diamondback Moth Ecology and Management: Problems, Progress and Prospects. Annual Review of Entomology, 58, 517-541. https://doi.org/10.1146/annurev-ento-120811-153605

[4] Verkerk, R.H.J. and Wright, D.J. (1996) Multitrophic Interactions and Management of the Diamondback Moth: A Review. Bulletin of Entomological Research, 86, 205216. https://doi.org/10.1017/S0007485300052482

[5] Gnago, J.A., Danho, M. and Agneroh, T.A. (2010) Efficacité des extraits de neem (Azadirachta indica) et de papayer (Carica papaya) dans la lutte contre les insectes ravageurs du gombo (Abelmoschus esculentus) et du chou (Brassica oleracea) en Côte d'Ivoire. International Journal of Biological and Chemical Sciences, 4, 953-966. https://doi.org/10.4314/ijbcs.v4i4.63035

[6] Odhiambo, J.A.O., Gbewonyo, W.S.K., Obeng-Ofori, D., Wilson, M.D., Boakye, D.A. and Brown, C. (2010) Resistance of Diamondback Moth to Insecticides in Selected Cabbage Farms in Southern Ghana. International Journal of Biological and Chemical Sciences, 4, 1397-1409. https://doi.org/10.4314/ijbcs.v4i5.65524

[7] Roux, O., Gevrey, M., Arvanitakis, L., Gers, C., Bordat, D. and Legal, L. (2007) ISSR-PCR: Tool for Discrimination and Genetic Structure Analysis of Plutella $x y-$ lostella Population Native to Different Geographical Areas. Molecular Phylogenetics and Evolution, 43, 240-250. https://doi.org/10.1016/j.ympev.2006.09.017

[8] Pichon, A. (1999) Caractérisation biologique et génétique de cinq populations d'origines géographiques différentes de Plutella xylostella (L.), Lepidoptera Yponomeutidae. Mémoire DEA Université de Rennes I, Rennes, 33p.

https://agritrop.cirad.fr/300491/

[9] Murthy, M.S., Sannaveerppanavar, V.T. and Shankarappa, K.S. (2014) Genetic Diversity of Diamondback Moth, Plutella xylostella L. (Yponomeutidae: Lepidoptera) Populations in Indi a Using RAPD Markers. Journal of Entomology, 11, 95-101. https://doi.org/10.3923/je.2014.95.101

[10] Tamura, K., Peterson, D., Peterson, N., Stecher, G., Nei, M. and Kumar, S. (2011) MEGA5: Molecular Evolutionary Genetics Analysis using Maximum Likelihood, Evolutionary Distance, and Maximum Parsimony Methods. Molecular Biology and Evolution, 28, 2731-2739. https://doi.org/10.1093/molbev/msr121

[11] Kimura, M. (1980) A Simple Method for Estimating Evolutionary Rate of Base Substitution through Comparative Studies of Nucleotide Sequences. Journal of Molecular Evolution, 16, 111-120. https://doi.org/10.1007/BF01731581

[12] Excoffier, L., Laval, G. and Schneider, S. (2005) Arlequin Ver. 3.1: An Integrated Software Package for Population Genetics Data Analysis. Evolutionary Bioinformatics Online, 1, 47-50. https://doi.org/10.1177/117693430500100003 
[13] Librado, P. and Rozas, J. (2009) DnaSP v5: A Software for Comprehensive Analysis of DNA Polymorphism Data. Bioinformatics, 25, 1451-1452. https://doi.org/10.1093/bioinformatics/btp187

[14] Excoffier, L., Smouse, P.E. and Quattro, J.M. (2006) Analysis of Molecular Variance Inferred from Metric Distances among DNA Haplotypes: Application to Human Mitochondrial DNA Restriction Data. Genetics, 131, 479-491. https://doi.org/10.1093/genetics/131.2.479

[15] Tamura, K. and Nei, M. (1993) Estimation of the Number of Nucleotide Substitutions in the Control Region of Mitochondrial DNA in Humans and Chimpanzees. Molecular Biology and Evolution, 10, 512-526.

[16] Saw, J., Endersby, N.M. and Mckechnie, S.W. (2006) Low mtDNA Diversity among Widespread Australian Diamondback Moth Plutella xylostella (L.) Suggests Isolation and a Founder Effect. Insect Science, 13, 365-373. https://doi.org/10.1111/j.1744-7917.2006.00105.x

[17] Li, J., Zhao, F., Choi, Y.S., Kim, I., Sohn, H.D. and Jin, B.R. (2006) Genetic Variation in the Diamondback Moth, Plutella xylostella (Lepidoptera: Yponomeutidae) in China Inferred from Mitochondrial COI Gene Sequence. European Journal of Entomology, 103, 605-611. https://doi.org/10.14411/eje.2006.081

[18] Niu, Y.Q., Nansen, C., Li, X.W. and Liu T.X. (2014) Geographical Variation of Plutella xylostella (Lepidoptera: Plutellidae) Populations Revealed by Mitochondrial COI Gene in China. Journal of Applied Entomology, 138, 692-700. https://doi.org/10.1111/jen.12130

[19] Chapman, J.W., Reynolds, D.R., Smith, A., Riley, J., Pedgley, D.E. and Woiwod I.P. (2004) High-Altitude Migration of the Diamondback Moth Plutella xylostella to the U.K.: A Study Using Radar, Aeral Netting, and Ground Trapping. Ecological Entomology, 27, 641-650. https://doi.org/10.1046/j.1365-2311.2002.00472.x

[20] Caprion, M.A. and Tabashnik A.E. (1992) Allozymes Used to Estimate Gene Flow among Populations of Diamondback Moth (Lepidoptera: Plutellidae) in Hawaii. Entomological Society of America, 21, 808-816. https://doi.org/10.1093/ee/21.4.808

[21] Lorimer, R.I. (1981) Lepidoptera Immigrants to Orkney in 1890. Proceedings and transactions of the British Entomological and Natural History Society, 14, 108-109.

[22] Wei, S.J., Shi, B.C., Gong, Y.J., Jin G.H., Chen X.X. and Meng X.F. (2013) Genetic Structure and Demographic History Reveal Migration of the Diamondback Moth Plutella xylostella (Lepidoptera: Plutellidae) from the Southern to Northern Regions of China. PLOS ONE, 8, Article ID: e59654.

https://doi.org/10.1371/journal.pone.0059654

[23] Yang J., Tian L., Xu, B., Xi W., Wang S., Zhang, Y., Wang X. and Wu Q. (2004) Insight into the Migration Routes of Plutella xylostella in China Using mtCOI and ISSR Markers. PLoS ONE, 10, Article ID: e0130905. https://doi.org/10.1371/journal.pone.0130905

[24] Herrero, S., Ferre, J. and Escriche, B. (2001) Mannose Phosphate Isomerase Isoenzymesin Plutella xylostella Support Common Genetic Bases of Resistance to Bacillus Thuringiensistoxins in Lepidopteran Species. Applied and Environmental Microbiology, 67, 979-981. https://doi.org/10.1128/AEM.67.2.979-981.2001

[25] Heckel, D., Gahan, L., Tabashnik, B. and Johnson, M. (1995) Randomly Amplified Polymorphic DNA Differences between Strains of Diamondback Moth (Lepidoptera: Plutellidae) Susceptible or Resistant to Bacillus Thuringiensis. Annals of the Entomological Society of America, 88, 531-537. https://doi.org/10.1093/aesa/88.4.531 